\title{
COVID-19 with pulmonary embolism: Case report
}

\section{Covid-19 ille birlikte görülen Pulmoner Emboli: Olgu}

\section{sunumu}

\author{
Hakan Celik ${ }^{1}$, Anwar Qais Saadoon ${ }^{2}$
}

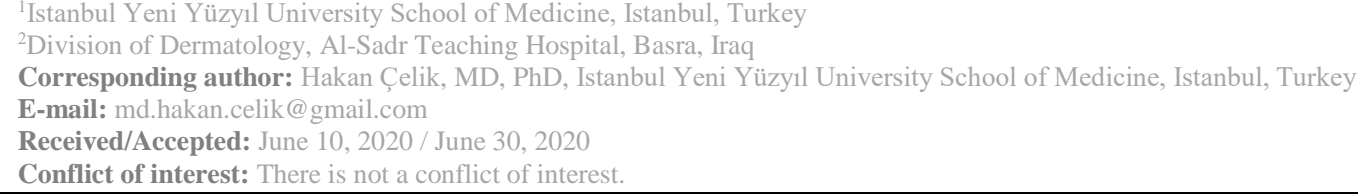

\section{SUMMARY}

A 20-years-old female patient presented to the emergency service due to complaints of sudden onset of severe shortness of breath; by a 3-day history of fever and a 1-day history of dry cough. After the patient evaluation, the presence of SARS-COV-2 infection together with the acute pulmonary embolism was detected. After the low molecular weight heparin was applied to the patient, the considerable increase was detected in the patient's oxygen saturation level. The acute pulmonary embolism can be seen after viral pneumonia. ${ }^{1}$ SARS-COV-2 pneumonia in comparison to the normal healtly population has much more embolism complication. In the evaluation stage, the request of contrast-enhanced tomography is crucial for the patients who have a high level of D-dimer and severe shortness of breath. The low molecular weight heparin that we use for treatment is given prophylactically in high-risk patients. ${ }^{3}$ In the reduction of anti-inflammatory response besides the protective effect of heparin; It is also known that IL-6 has binding properties at recent publications. ${ }^{4}$ In our case, We evaluated microthrombosis and large-vessel thrombosis may coexist in SARS-Cov-2 pneumonia and the effect of heparin.

Keywords: COVID-19, pulmonary embolism, chest computed tomography with contrast, heparin

\section{ÖZET}

20 yaşında kadın hasta ani nefes darlı̆ğ, 3 gündür süren ateş,1 gündür devam eden kuru öksürük şikayetleri ile acil servise başvurdu. Hasta değerlendirildikten sonra SARS-Cov-2 enfeksiyonu ile akut pulmoner emboli birlikteliği görüldü. Hastaya verilen düşük molekül ağırlıklı heparin sonrası oksijen satürasyonunda önemli artış görüldü. Viral pnömoni sonrası akut pulmoner emboli görülebilir. ${ }^{1}$ SARS-Cov-2 pnömonilerinde normal sağlıklı popülasyona kıyasla daha fazla emboli görülebilmektedir. ${ }^{2}$ Tetkik kısmında kan D-dimer yüksekliği olan yada olmayan ve ani nefes darlığı olan hastalara kontrastlı tomografi tetkiki istenmesi önemlidir. Tedavide kullandığımız düşük molekül ağırlıklı heparinin yüksek riskli hastalarda profilaktik olarak verilmektedir. ${ }^{3}$ Heparinin sadece tromboz koruyucu etkisi yanında antiinflamatuvar yanıtın da azaltılmasında; IL-6 bağlayıcı özelliğin de olduğu bilinmektedir. ${ }^{4}$ Vakamızda SARS-Cov-2 pnömonisinde mikrotromboz ve büyük damar trombozunun birlikte olabileceği aynı zamanda heparinin etkisine değinilmiştir. Anahtar sözcükler: COVID-19,pulmoner emboli,heparin 


\section{INTRODUCTION}

The SARS-COV-2 virus is a new type of virus that the world has just known and has had to stop. ${ }^{1}$ The World Health Organization (WHO) has identified this infection as a pandemic. The symptoms and complications caused by SARSCOV-2 virus are not well known. In our case report, we mention the combination of SARSCOV-2 pneumonia and embolism, and low molecular weight heparin may be an important role in its treatment.

\section{CASE REPORT}

A 20-year-old Turkish female patient from Istanbul presented to the emergency department with sudden onset of severe shortness of breath, preceded by a 3-day history of fever and 1-day history of dry cough. She has no recognized predisposing factors for venous thromboembolism. On physical examination, she had tachycardia, tachypnea, and her oxygen saturation was $84 \%$ with $\mathrm{O} 2$. Laboratory test results revealed hemoglobin 13.9 (normal range 11-16.5) g/dL, lymphocytes 0.51 (normal range $0.8-4$ ) $\mathrm{G} / \mathrm{L}$, neutrophils 8.94 (normal range 2-7) G/L, platelets 165 (normal range 150-450) G/L, Creactive protein (CRP) 68.4 (normal range 0.8 3) $\mathrm{mg} / \mathrm{L}$, troponin $\mathrm{T} 0.281$ (normal value <0.04) $\mathrm{ng} / \mathrm{mL}$, procalcitonin 0.158 (normal range $0.1-0.49) \mathrm{ng} / \mathrm{mL}$, and D-dimer 3410 (normal value $<250$ ) $\mathrm{ng} / \mathrm{mL}$. The baseline electrocardiography (ECG) was normal. Chest computed tomography (CT) with intravenous contrast showed ground-glass opacities with vascular dilatation predominately located at the anterior segment of the left upper lobe with a concomitant acute pulmonary embolism in the right main pulmonary artery as well as the anterior segmental pulmonary arteries of the left upper lobe (Figure1). A real-time RT-PCR testing confirmed the infection with SARS$\mathrm{CoV}-2$. Based on these findings, the diagnosis of COVID-19 pneumonia complicated by acute pulmonary embolism has been made. Treatment with low molecular weight heparin (LMWH), hydroxychloroquine, and azithromycin has been started and the patient has been admitted to the intensive care unit where her oxygen saturation increased to $93 \%$ with $\mathrm{O} 2$.

\section{DISCUSSION}

Viral pneumonia can be complicated by acute pulmonary embolism. ${ }^{1}$ Disturbed coagulation function has been reported in patients infected with SARS-CoV-2 more than healthy controls. ${ }^{2}$ Therefore, it is wise to perform contrasted chest CT scan for patients with COVID-19 pneumonia who present with sudden onset of dyspnea or those with elevated D-dimer to exclude pulmonary embolisim. ${ }^{1}$

Furthermore, in the absence of contraindication, prophylactic LMWH is recommended for patients with COVID-19 pneumonia who requiring hospital admission to prevent thromboembolism, even in the absence of other risk factors. ${ }^{3}$ There is a correlation between hypercoagulability and Ddimer level in COVID-19 infections. ${ }^{4}$ However, although the micro-coagulation mechanism is well explained by immune-thromboembolism; Largevessel thromboembolism is not well explained. As the disease secondary to the increase in cytokine level is a more mortal survey for the patients, agents to correct this situation have been used. One of them is tocilizumab (IL-6 receptor antagonist). ${ }^{6}$ The IL- 6 binding property of heparin, which is also used in our case, has been described in previous publications. ${ }^{5}$ Although heparin appears not only as an anti-thrombosis agent, it is also obvious that it contributes to the recovery of patients due to its anti-inflammatory effects. This benefit is thought to be effective not only in the coagulation mechanism but also in its anti-inflammatory properties. $^{7}$ It is thought that both microcoagulation and macro-coagulation that are prominent in our case may be related. Microvascular coagulation is considered in the approach to patients, but macrovascular coagulation can be neglected. This topic needs further investigation in the next days. In patients with COVID-19 infection and risk factors, contrast thorax computer-tomography scan will help to notice coagulation disorders that may occur without D-dimer elevation. The presence of heparin in treatment should be investigated in antiinflammatory aspects. 


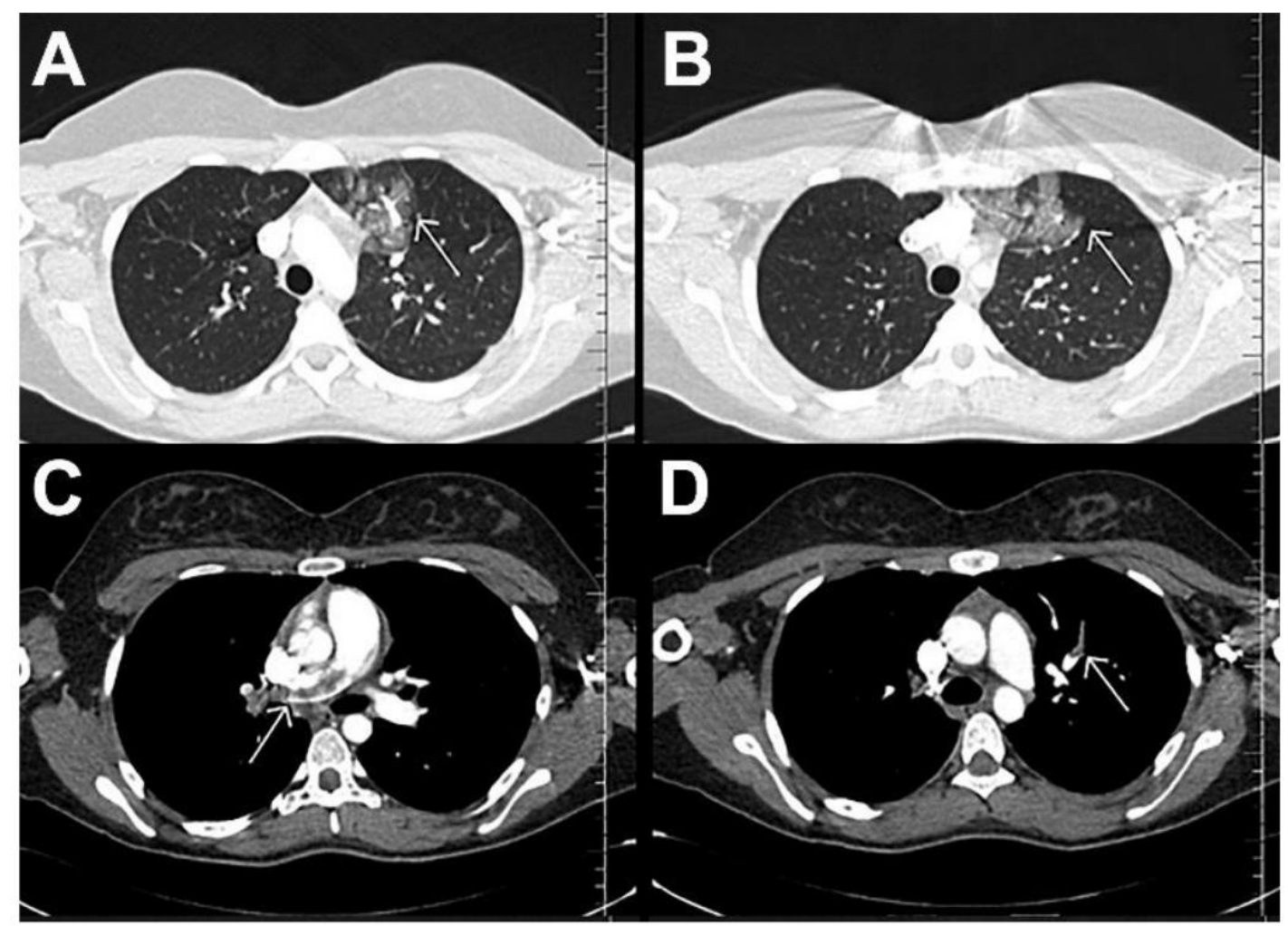

Figure 1: Axial contrast-enhanced chest computed tomography (CT) of 20-year-old female shows ground-glass opacities with vascular dilatation predominately located at the anterior segment of the left upper lobe (A and B) with a concomitant acute pulmonary embolism in the right main pulmonary artery $(C)$ and anterior segmental pulmonary arteries of the left upper lobe (D).

\section{REFERENCES}

1. Jolobe OMP. Similarities between community-acquired pneumonia and pulmonary embolism. Am J Med 2019;132:e863.

2. Han H, Yang L, Liu R, Liu F, Wu KL, Li $\mathrm{J}$, et al. Prominent changes in blood coagulation of patients with SARS-CoV2 infection. Clin Chem Lab Med 2020;16.

3. Rotzinger DC, Beigelman-Aubry C, von Garnier C, Qanadlia SD. Pulmonary embolism in patients with COVID-19: Time to change the paradigm of computed tomography. Thromb Res 2020;190:5859.
4. R.S. Mummery, C.C. Rider Characterization of the heparin-binding properties of IL-6 J Immunol, 2000; 165 : 5671-5679.

5. Guaraldi, G, Meschiari M, Cozzi-Lepri A,et al. Tocilizumab in patients with severe COVID19: a retrospective cohort study. The Lancet Rheumatology 2020.

6. Tang N, Li D, Wang X, Sun Z. Abnormal coagulation parameters are associated with poor prognosis in patients with novel coronavirus pneumonia. J Thromb Haemost. 2020; 18(4): 844- 847.

7. Thachil J. The versatile heparin in COVID-19. J Thromb Haemost. 2020;18(5):1020-1022. 